Boško Francuski

Fakultet političkih nauka

Beograd

Biljana Đorić Francuski

Filološki fakultet, Beograd
004.738.5:655.41

https://doi.org/10.18485/filkult.2016.1.ch4

\title{
TRADICIONALNA ILI E-KNJIGA, PITANJE JE SAD ${ }^{1}$
}

\section{Sažetak}

Elektronska knjiga proslavila je već svoj četrdeseti rođendan i postaje sve popularnija širom sveta. Poznata još pod nazivom digitalna, on-lajn ili e-knjiga, ona za razliku od tradicionalne, klasične, štampane knjige - predstavlja virtuelnu, odnosno, ekransku strukturu, budući da se tekst ne nalazi na stranicama nego na ekranu. Međutim, uprkos stalnom pojavljivanju novih i modernijih tehnologija, štampana knjiga kao kulturološki oblik opstaje i u dvadeset i prvom veku. Mada su u svetu brojne studije posvećene odnosu savremenog elektronskog izdavaštva i tradicionalne štampane literature, u našoj akademskoj javnosti nije dovoljno istražena pojava e-knjiga i mogućnosti prenosa informacija pomoću ove vrste štiva. Stoga će u ovom radu biti obrađeni podaci dobijeni na osnovu ankete sprovedene među studentima sa različitih fakulteta Univerziteta u Beogradu, kako bi se makar donekle rasvetlilo pitanje opstanka 'stare', 'opipljive', 'papirnate' knjige u našoj sredini. Upitnik koji su studenti popunjavali sadrži pitanja zatvorenog tipa koja pružaju kvantitativne podatke, ali i otvorenog tipa čija je svrha da se ti brojčani rezultati dopune kvalitativnim podacima. Odgovore na pitanja postavljena u anketi davali su studenti raznih godina studija i životnog doba, tako da ovi ispitanici predstavljaju reprezentativni uzorak, a cilj ovog rada je da se komparativnom analizom dobijenih odgovora i dedukcijom na osnovu prikupljenih podataka utvrde njihove navike pri čitanju elektronskih i štampanih knjiga, kao i mišljenja o razlikama između ova dva vida štiva.

Ključne reči: tradicionalna knjiga, elektronska knjiga, anketa, studenti, Univerzitet u Beogradu

$1 \quad$ Ovaj rad je deo istraživanja koja se izvode na projektu Društvene krize i savremena srpska književnost i kultura: nacionalni, regionalni, evropski i globalni okvir (br. 178018), koji finansira Ministarstvo prosvete i nauke Republike Srbije. 


\section{Uvod: pojava i istorijat elektronske knjige}

Elektronska knjiga je knjiga u digitalnom obliku, pa se upravo zato kod nas još naziva digitalna knjiga ili on-lajn knjiga, a po terminu na engleskom jeziku (e-book) takođe i e-knjiga. Za razliku od tradicionalne, klasične, štampane knjige, ona predstavlja virtuelnu, to jest, ekransku strukturu, jer se tekst nalazi na ekranu umesto na 'opipljivim', 'papirnatim' stranicama. To je izum koji je omogućio čitanje i pregled sadržaja knjiga uz pomoć određenih programa ili posebnih aparata koji tome služe - čitača elektronskih knjiga (ili na engleskom jeziku: e-reader, što je skraćeno od electronic reader). Osim na ovim aparatima, koji su namenjeni isključivo prelistavanju elektronskih knjiga, one se mogu čitati na gotovo bilo kom modernom uređaju sa ekranom - računarima, mobilnim telefonima, tabletima i slično.

Elektronska knjiga kao izum nije nastala preko noći, te je nemoguće tačno odrediti ko je prvi došao do te ideje. I pored toga, zasluga za začetak ideje o modernoj elektronskoj knjizi često se pripisuje američkom autoru Majklu Hartu (Michael S. Hart), koji je prevashodno poznat kao osnivač Projekta Gutenberg (Project Gutenberg). Ovaj projekat osnovan je 1971. godine sa ciljem da se u elektronski format pretvori, a zatim i objavi, što više knjiga i dokumenata u obliku tekstualnih fajlova. Ti fajlovi su putem interneta dostupni za korišćenje svim korisnicima, i uglavnom su besplatni. Majkl Hart je dao sebi, a kasnije i svojim volonterima, za zadatak da fizičke tekstove ručno pretvaraju u digitalni format. Prvi ovako obrađen tekst bila je američka Deklaracija nezavisnosti.

Uprkos velikoj volji ovih ljudi da javnosti poklone nešto što bi moglo da promeni sâm koncept knjige, nedostajala je adekvatna tehnologija koja bi podigla Projekat Gutenberg na viši nivo. Tek kasnih devedesetih godina dvadesetog veka pojavile su se neke od prvih verzija modernih čitača elektronskih knjiga - kao, na primer, čitač Bookman kompanije Soni (Sony), koji je bio suviše skup da bi zaživeo. Ovo je ipak bila, može se reći, bura pred zatišje, jer bez jednog usaglašenog formata, i imajući u vidu da su ovi aparati bili nepraktični i relativno komplikovani, koraci napravljeni ka modernoj elektronskoj knjizi bili su gotovo nepostojeći. Nakon pauze od skoro deset godina, kompanija Soni je 2006. godine proizvela Sony Reader - čitač koji je rešio probleme udobnosti, praktičnosti i, donekle, 
objedinjenosti elektronskog formata. Ovaj čitač je takođe bio povezan sa sopstvenom onlajn knjižarom, što je u nekoj meri uvećalo dostupnost materijala za čitanje.

Uređaj koji je najviše doprineo popularnosti elektronske knjige izdala je sledeće godine kompanija Amazon. Kršten imenom Kindle, ovaj aparat je doživeo nezapamćenu popularnost - bio je jednostavan za korišćenje, a odmah po izlasku je bio dostupan katalog sa veoma velikim brojem knjiga koje, pritom, nisu bile ni mnogo skupe. Ovaj uspeh doveo je do pojave nekoliko rivala na tom konkretnom tržištu (Apple, Google, itd.), ali Amazon do danas ostaje neprikosnoveni predvodnik u oblasti elektronskih knjiga.

Veoma važan faktor za popularizaciju elektronskog štiva bio je i takozvani 'otvoreni pristup' (Open Access), koji uglavnom uključuje naučne časopise u elektronskom obliku, koji su tako postali dostupni naučnicima i istraživačima širom sveta. Kao što navodi Bogdan Trifunović, glavna privlačnost ovog projekta su besplatan pristup tekstovima, veoma laka dostupnost i mogućnost povratne reakcije (Trifunović 12). I najzad, najveći korak napravila je 2005. godine kompanija Gugl (Google) sa projektom koji je nazvala sasvim jednostavno 'pretraživač knjiga' (Google Book Search), a predstavlja ogromnu besplatnu elektronsku biblioteku.

Značajno je još napomenuti da "u digitalnom svetu koji već živimo" (Kovačević 24) - a koji Kuver naziva "svetom video prenosa, mobilnih telefona, telefaksa, kompjuterskog umrežavanja"2 (Coover) - na ovaj način klasična knjiga dobija svoju suparnicu, pa mnogi predviđaju "da je štampani medijum osuđen na propast kao zastarela tehnologija, običan kuriozitet iz prohujalih dana čija je sudbina da uskoro zauvek bude smešten u one prašnjave zapuštene muzeje koje sada nazivamo bibliotekama" ${ }^{3}$ (Coover). Nasuprot tome, "e-knjige upućuju na postojanje jednog sveta koji se može nazvati digitalni, informatički, virtuelni [...] Ove knjige bi zapravo mogle pripadati samo onom delu aristotelovske trijade koji se otpisuje kao „samo mogućnost“ ili ,još-ne-stvarnost“.” (Kovačević 25), a to će pokazati i rezultati istraživanja prikazanog u ovom radu.

2 "in the world of video transmissions, cellular phones, fax machines, computer networks" (prevod autora rada)

3 "that the print medium is a doomed and outdated technology, a mere curiosity of bygone days destined soon to be consigned forever to those dusty unattended museums we now call libraries" (prevod autora rada) 


\section{Studija slučaja: rezultati ankete}

To istraživanje sprovedeno je tokom 2015. godine na Fakultetu političkih nauka i na Filološkom fakultetu Univerziteta u Beogradu, na kojima su zaposleni autori ovog rada. Po pedeset studenata sa ova dva fakulteta popunjavalo je anketu koja se sastoji od šest pitanja. Odgovore na pitanja postavljena $u$ anketi davali su studenti raznih godina studija i različitog životnog doba, tako da ovi ispitanici predstavljaju reprezentativni uzorak. Upitnik koji su studenti popunjavali sadrži pitanja zatvorenog tipa koja pružaju kvantitativne podatke, ali i otvorenog tipa čija je svrha da se ti brojčani rezultati dopune kvalitativnim podacima. Studenti su odgovarali na sledeća pitanja:

1. Koliko imate godina i na kojoj ste godini studija (primer odgovora: 22/4)?

2. Ako za neku knjigu imate izbor između elektronskog ili tradicionalnog formata, za koji ćete se radije opredeliti? (ponuđeni odgovori: elektronska knjiga, tradicionalna knjiga, zavisi)

3. Ukoliko ste na drugo pitanje odgovorili sa "Zavisi", kratko obrazložite od čega zavisi.

4. Ukoliko čitate elektronske knjige:

- Kada ste počeli sa čitanjem elektronskih knjiga?

- Da li ih od tada čitate sve više, sve ređe ili istom učestalošću?

5. Od poslednjih 10 knjiga koje ste pročitali, koliko je bilo elektronskih a koliko tradicionalnih (na primer: $2 / 8$ znači dve elektronske a 8 tradicionalnih)?

6. U nekoliko rečenica subjektivno opišite prednosti i mane elektronske i tradicionalne knjige.

$U$ anketi na Fakultetu političkih nauka sastav ispitanika bio je sledeći: 24 studenta sa prve godine studija (48\%) - uzrasta 19-22 godine, 19 studenata sa druge godine studija (38\%) - uzrasta 20 -22 godine, 3 studenta sa treće godine studija (6\%) - uzrasta $21-23$ godine, 3 studenta sa četvrte godine studija (6\%) - uzrasta $22-23$ godine i jedan student sa pete godine studija (2\%) - uzrasta 23 godine.

Na pitanje "Ako za neku knjigu imate izbor između elektronskog ili tradicionalnog formata, za koji ćete se radije opredeliti?" 4 ispitanika (8\%) odabrala su ponuđeni odgovor elektronska knjiga, 41 ispitanik (82\%) se 
opredelio za odgovor tradicionalna knjiga, a njih petoro (10\%) je odgovorilo da zavisi. Dakle, od ukupnog broja ispitanika, najveći broj studenata odabrao je tradicionalnu knjigu, dok je približno jednak broj ispitanika dao odgovor da će pre odabrati elektronsku knjigu i da izbor zavisi.

Od čega zavisi izbor bilo je upravo treće pitanje otvorenog tipa, na koje su odgovarali samo ispitanici koji su na prethodno pitanje dali taj odgovor. Od tih pet studenata, jedna osoba je ostavila prazno mesto za odgovor, a dve su odgovorile potpuno isto: "O čemu se radi, koji je predmet knjige", dok su preostali ispitanici odgovorili: "Od trenutnog raspoloženja i situacije, materije kojom se predmet bavi" i "Naučno štivo - elektronski format; beletristika/književna dela - tradicionalni".

Odgovori na četvrto pitanje - "Kada ste počeli sa čitanjem elektronskih knjiga i da li ih od tada čitate sve više, sve ređe ili istom učestalošću?" - bili su veoma raznovrsni i prilično neujednačeni, kako za prvi tako i za drugi deo odgovora. Naime, ako se izuzme 8 ispitanika (16\%) koji nisu popunili ovo pitanje, najveći broj ispitanika - njih 19 (što je 38\%) čita elektronske knjige od pre dve godine, 7 ispitanika (14\%) već tri godine, po 5 studenata (10\%) ih ne čita uopšte ili ih čita tek godinu dana, dok po dva ispitanika (4\%) navode da ih čitaju od skoro, to jest, četiri i pet godina. Ono što je zanimljivo u ovom delu ankete je odgovor jednog ispitanika: "Nisam počeo" - iz čega proizilazi nagoveštaj da će možda početi, kao i sledeća dva odgovora u kojima se pored vremenske distance daje i obrazloženje (reklo bi se čak opravdavanje) za čitanje elektronskih knjiga: "Kada nisam mogla da pronađem željene knjige u biblioteci" $i$ "Kada sam krenula na fakultet. Prvi razlog je jer su mi često potrebne knjige koje nisam mogla da nađem u štampanom izdanju, a drugi razlog je ušteda novca". Ispitanici su takođe i na drugi deo pitanja dali veći raspon odgovora. U skladu sa prethodnim pitanjem, i ovde je broj ispitanika koji nisu popunili ovo polje ili navode da uopšte ne čitaju elektronske knjige isti kao u prethodnom slučaju, to jest $8(16 \%)$ i $5(10 \%)$ studenata, respektivno. Od ostalih ispitanika, najveći broj - njih 15 (30\%) odgovorio je da sa istom učestalošću čita elektronske knjige, njih 10 (20\%) to čini sve ređe, a 5 (10\%) sve više. Čak sedam ispitanika je na ovo pitanje odgovorilo prilično neodređeno, i to na način koji još više od gore navedenih odgovora asocira na opravdavanje za pribegavanje ovom vidu štiva - stiče se utisak, samo kad se mora. Evo najzanimljivijih odgovora: "Generalno ne čitam [elektronske knjige] često 
jer više volim tradicionalni oblik knjige, ali povremeno čitam knjige na engleskom jer u Beogradu nema mnogo knjižara koje prodaju strana izdanja te je lakše čitati sa laptopa", "Čitam ih po potrebi", "kada nemam alternativu u tradicionalnim", "Kada god mogu opredeljujem se za tradicionalne knjige, tako da digitalna izdanja čitam samo kada moram", a evo i dva odgovora kojima ispitanici otvoreno i neskriveno ukazuju na nepopularnost ove vrste knjiga kod nas: "Kada sam primorana" i "Samo kada sam vremenski ograničen".

Peto pitanje glasilo je: "Od poslednjih 10 knjiga koje ste pročitali, koliko je bilo elektronskih a koliko tradicionalnih?" Odgovori na ovo pitanje takođe su raznoliki, ali - što je još važnije - ukazuju na činjenicu da čak i oni koji čitaju elektronske knjige to ne čine baš često, makar ne u odnosu prema štampanim izdanjima. Naime, 16 ispitanika (32\%) navodi da su sve pročitane knjige bile tradicionalne, to jest, štampane, a isti taj broj studenata opredeljuje se za odgovor osam štampanih i dve elektronske knjige; približno jednak broj ispitanika pročitao je samo jednu elektronsku knjigu - 6 studenata (12\%) ili četiri elektronske a šest tradicionalnih - 7 studenata (14\%); dok je tri elektronske u odnosu prema sedam štampanih pročitalo troje ispitanika (6\%); a podjednak broj ili blagu prednost elektronskim knjigama - šest prema četiri, daje samo po jedan ispitanik (po 2\%).

Na poslednje pitanje otvorenog tipa su, kao što je to i očekivano, dobijeni najinteresantniji odgovori, pa će ovde biti navedeni neki primeri. Kao prednosti elektronske knjige ispitanici su uglavnom navodili: da je dostupna svima, lako prenosiva, može da se čita svuda i na svakom mestu, jeftinija je (neki studenti napominju da se veliki broj ovih knjiga besplatno može skinuti sa interneta), mogućnost podvlačenja i veća preglednost teksta, ne zauzima prostor i lakše se do nje dolazi (neki ispitanici pravdaju svoj odabir elektronske a ne tradicionalne knjige time što ne mogu ovu drugu da nabave u biblioteci ili nije prevedena na srpski). Najpotpuniji opis pogodnosti koje pruža čitanje ove vrste teksta navode sledeća dva ispitanika: "Male veličine fajlova, vrlo pokretne, nema savijanja listova, nema pozajmljivanja prijateljima, nema otisaka od hrane i pića, podvlačenje uredno, kopiranje moguće ... velike prednosti na strani e-knjige" i "Elektronska: prednosti - "mali milion" tradicionalnih knjiga može stati u elektronskom uređaju, lako prenosiva, praktična, lako skidanje knjiga sa neta ...". Od mana elektronske knjige najčešće su navedene sledeće: 
brzo zamaranje vida pri čitanju štiva na ekranu, zbog čega se može pojaviti i glavobolja, pad koncentracije i brži gubitak interesovanja jer "dosadno je da buljiš u ekran" (pa čak jedan ispitanik navodi da "stvari koje se pročitaju [u štampanom obliku] ostaju duže u sećanju"), sporije se čita, ${ }^{4}$ a takođe postoji opasnost da će se baterija na telefonu ili tabletu isprazniti.

Prednosti tradicionalne knjige po mišljenju ispitanika su: lakše rukovanje i prelistavanje, mogućnost čitanja i tamo gde nema interneta, duže čitanje jer se oči manje zamaraju, preglednost, veća zainteresovanost, pa čak i "mnogo bolje doživljena radnja u knjizi”, a mnogi studenti pomenuli su lepši osećaj dok čitaju štampani tekst zbog mirisa, dodira i šuštanja papira. Nasuprot tome su mane tradicionalne knjige to da košta više od elektronske, teže je prenosiva, zauzima mnogo mesta, može da se izgubi ili pocepa, teže se do nje dolazi (mora se otići do knjižare ili biblioteke, dok se elektronski tekst jednim klikom na miša skida sa interneta), nekad su slova suviše sitna ili izbledela, a jedan ispitanik čak kao manu navodi to da "je u pitanju papir - čuvajmo drveće!"

Osim gore navedena dva povoljna mišljenja o elektronskoj knjizi, svi ostali ispitanici dali su prednost tradicionalnoj knjizi i to tako da je pored praktičnih razloga bilo i nekoliko prilično poetskih ocena, na primer: "lepše se čita kada je tradicionalna knjiga, imati je u ruci, gledati korice ..."; "Tradicionalni format, međutim, ima "dušu", za razliku od elektronskog"; "Sa tradicionalnom knjigom mogu da se povežem mnogo više nego sa elektronskom, mogu da je čuvam na polici i držim u ruci, mogu da prelistavam stranice i više je osećam kao živu materiju"; "Prednost tradicionalne knjige je to što mogu da se osetim povezano sa njom, stvara neki osećaj bliskosti izmedju čitaoca i knjige"; "Tradicionalne knjige služe da stoje na polici i da se stalno iščitavaju" ili "Drugačiji je doživljaj dela kada imate knjigu u rukama", odnosno, sasvim jednostavno: "Lepši osećaj, pa čak i miris, papir je papir - užitak veći", pa zato jedan ispitanik odlučno zaključuje sledeće: "Meni lično elektronska knjiga nikad neće moći da zameni tradicionalnu knjigu." Ovo je potpuno u skladu sa Kuverovim mišljenjem, kada tvrdi da je moć knjige velikim delom "u liniji, tom obavezujućem po-

$4 \quad$ Kako navodi Trifunović, ovo je i naučno dokazana činjenica: “U potrazi za razlogom zašto ljudi više vole da čitaju sa papira nego da gledaju u monitor, istraživači su došli do zanimIjivih otkrića. Ispostavilo se da je brzina čitanja teksta sa monitora za trećinu manja od brzine čitanja sa papira." (Trifunović 9) 
kretu koji nam nameće autor, od početka rečenice do njene tačke, od vrha stranice do njenog dna, od prve strane do poslednje." ${ }^{1}$ (Coover)

Slične rezultate dalo je i istraživanje na Filološkom fakultetu, u kome je učestvovalo po 12 studenata (po 24\%) sa prve i četvrte godine studija uzrasta 18-19 godina za brucoše, a 21-25 godina za apsolvente, 16 studenata sa druge godine studija (32\%) - uzrasta $19-27$ godina i 10 studenata sa treće godine studija (20\%) - uzrasta 20-26 godina.

Na pitanje da li će se radije opredeliti za elektronski ili tradicionalni format knjige, najveći broj ispitanika - 43 (odnosno 86\%) opredelio se za tradicionalnu knjigu, dok nijedan ispitanik nije dao odgovor da će pre odabrati elektronsku knjigu (0\%), a za odgovor zavisi opredelilo se 7 ispitanika (to jest 14\%). Od tih sedam ispitanika, dve osobe navele su da opredeljivanje za format knjige zavisi od dostupnosti, tri odgovora odnosila su se na cenu knjige, dok su preostala dva ispitanika odgovorila da izbor zavisi od veličine, odnosno dužine knjige, pri čemu je jedna osoba objasnila da u slučaju obimnijeg štiva više voli tradicionalnu knjigu pošto ona manje škodi vidu.

Što se tiče odgovora na četvrto pitanje ("Kada ste počeli sa čitanjem elektronskih knjiga i da li ih od tada čitate sve više, sve ređe ili istom učestalošću?"), 10 ispitanika (20\%) nije uopšte popunilo mesto za odgovor, najveći broj ispitanika - 13 (što je 26\%) čita elektronske knjige od pre tri godine, 10 ispitanika (20\%) već dve godine, 6 studenata (12\%) ih čita više od pet godina, 5 četiri godine (10\%), 4 ispitanika (8\%) navode odgovor pet godina, a dvoje godinu dana (4\%). Odgovori na drugi deo pitanja slični su kao u anketi na Fakultetu političkih nauka: najveći broj ispitanika - njih 14 (28\%) odgovorio je da sa istom učestalošću čita elektronske knjige, njih $13(26 \%)$ to čini sve češće, $12(24 \%)$ sve ređe, dok 11 studenata (22\%) nije uopšte odgovorilo na ovo pitanje, a jedna osoba (2\%) je odgovorila: "Izbegavam da ih čitam kad god mogu naći fizički primerak, tako da ih ne čitam češće". Indikativno je da su ovo pitanje uglavnom preskočili ispitanici koji su na sledeće pitanje ili odgovorili rečenicom da su sve knjige od poslednjih deset koje su pročitali bile tradicionalne ili dali odgovor 0/10 koji ima isto to značenje (a jedna osoba ga čak naglašava potpunijim odgovorom: "10/10 u korist tradicionalnih").

$5 \quad$ "in the line, that compulsory author-directed movement from the beginning of a sentence to its period, from the top of the page to the bottom, from the first page to the last" (prevod autora rada) 
Sličnost sa procentualnom slikom $u$ istraživanju sprovedenom na Fakultetu političkih nauka očigledna je i kada se pogledaju odgovori na peto pitanje: najveći broj ispitanika - njih 15 (30\%) navodi da su sve pročitane knjige bile tradicionalne, na drugom mestu su dve elektronske knjige u odgovorima 8 studenata (16\%), zatim slede tri elektronske kod 7 ispitanika (14\%), jedna kod 6 (12\%), dok je po četiri elektronske a šest tradicionalnih i osam elektronskih a dve tradicionalne pročitalo po 4 studenta (po $8 \%)$, podjednak broj (5/5) navode tri studenta (6\%), sedam elektronskih dva ispitanika (4\%) i šest elektronskih u odnosu na četiri tradicionalne jedan ispitanik (2\%).

Na osnovu odgovora datih na poslednje pitanje, može se zaključiti da su prema mišljenju reprezentativnog uzorka studenata Filološkog fakulteta u Beogradu prednosti elektronskih knjiga dostupnost i pristupačnost; ne zauzimaju puno prostora i često su besplatne; praktičnije su, naročito tokom putovanja ili dok se čeka u redu jer može da se čita preko telefona ili laptopa; lakše se čuvaju, stranice se ne mogu pohabati ili pocepati; postoji mogućnost prilagođavanja veličine slova, dodavanje beleški, lako pronalaženje ključnih reči i delova koji interesuju upravo onoga ko ih čita. Od mana elektronske knjige ispitanici su naveli da se kvari vid i boli glava; lako se može izgubiti zbog virusa; dosadno je i naporno čitati zureći u ekran, ona nije stvarna nego virtuelna.

Međutim, mane poseduje i tradicionalna knjiga, a to je da košta više od elektronske; kao i da se teško drži u rukama, naročito ako je 'glomazna'. Prednosti tradicionalnih knjiga su da je neuporedivo lepši osećaj i veći užitak čitati ih; da je miris knjiga specifičan; studenti Filološkog fakulteta više vole da okreću stranice i da stave knjige u svoju biblioteku; a evo i dva lepa mišljenja koja mogu poslužiti kao zaključak za ovaj deo rada: "Više drži pažnju i bolja za one koji se bave književnošću i analiziraju dela"; "Smatram da elektronska knjiga nikad ne može (i ne treba) da zameni čari mirisa 'knjige u pravom smislu reči' i okretanja strana".

\section{Zaključak}

Mišljenja naših teoretičara u vezi sa ovim poslednjim pitanjem $u$ anketi su oprečna. Trifunović ukazuje na to da je prednost elektronske knjige 
u "lakoj razmenljivosti i mogućnosti čitanja i pretraživanja na više uređaja" (Trifunović 5), kao i ogromnom protoku teksta preko interneta. Međutim, on takođe smatra i da "popularnost „obične“, papirne knjige još uvek nije ugrožena. Knjige ne doživljavamo samo kao nosioce informacija - one su predmeti koji deluju na naše čulo vida, dodira, ponekad i mirisa. Fina tipografija, bogato ukrašene korice i diskretno obojen papir, svoj smisao i značaj imaju jedino u klasičnim knjigama, koje se čvrsto mogu stegnuti šakama." (Trifunović 5) Ovo upravo pokazuju i rezultati ovde analizirane ankete, gde se vidi nekoliko odgovora sličnih narednoj konstataciji Bogdana Trifunovića: "Dok čitate knjigu tekst na njenim stranicama kao da je vaš, kao da ste u neposrednom dodiru sa piscem. Sa slovima na ekranu teže je ostvariti takav kontakt." (Trifunović 6)

To su sve razlozi zbog kojih ovaj autor zaključuje "da klasična, papirna knjiga predstavlja nezaobilazni segment ljudske kulture čitanja, ophođenja i življenja, objekat snažnog psihološkog uticaja na čoveka, koji ne posustaje u „digitalnoj eri“. Elektronska knjiga je, još uvek, odojče koje treba da poraste kroz širu primenu i naviku ljudi da je koriste u svakodnevnom radu i komunikaciji." (Trifunović 18) S druge strane, čuju se i ovakva mišljenja: "lako te razlike, ipak, nisu nepomirljive, digitalne tehnologije se i dalje doživljavaju kao neprijatelji knjige. Učitelji, pedagozi i naučnici i dalje zastupaju tezu da je internet neprijatelj čitanja, tvrdeći da ovaj okean nehijerarhizovanih informacija predstavlja suštu suprotnost sistematičnom znanju jer podstiče na ekransku strategiju percepcije koja se svodi na slučajan izbor hiperlinkova koji unedogled raslojavaju ponuđene sadržaje." (Gordić-Petković 177)

Nešto specifičnije, naši stručnjaci navode prednosti elektronske knjige, recimo: "Elektronski tekst može se pretraživati, mogu se sređivati veličina i font teksta prema ličnom ukusu, ispravljati eventualne greške ili dorađivati prevod, hiperlinkovi mogu sa jedne stranice upućivati na drugu, knjige su dostupne odmah nakon kupovine u on-lajn knjižari, dvadesetčetvoročasovna dostupnost (nezavisno od rada biblioteka ili broja primeraka knjige u fondu), mogućnost štampanja knjige na zahtev, smeštanje čitave biblioteke u prenosni računar... Pored toga, elektronske knjige su znatno jeftinije, tiraž se ne može iscrpeti, a autori i izdavači su u prilici da ostvare veći profit i brže udovolje zahtevima čitalačke publike." (Trifunović 9) Ali, uprkos ove dve činjenice: "Proizvodi moderne štamparske prese 
imaju svoja ograničenja. Štampane knjige podložne su fizičkom propadanju i zahtevaju dosta vremena i prostora." (Trifunović 9) Trifunović smatra da "Publikacije u elektronskom obliku nikako nisu velika pretnja štampanim verzijama, jer čitaocu uvek ostaje izbor za kupovinu određenog papirnog primerka. Štampane knjige bolje služe za neprekidno duže čitanje, dok je elektronska distribucija informacija bolja za razmenu podataka i manjih paketa informacija." (Trifunović 10) Zato on zaključuje, slično kao većina ispitanika u anketi analiziranoj u ovom radu, sledeće: “Koju knjigu koristiti, papirnu ili elektronsku, zavisi od situacije, okolnosti, mogućnosti, ali i navika." (Trifunović 18)

I drugi autori ukazuju na različitost pristupa knjizi kao štampanom tekstu i kao ekranskoj strukturi, na primer: "Štampano štivo traži od čitaoca usredsređenje i nudi mu monovalentnu informaciju, dok elektronsko štivo zahteva raslojavanje čitaočeve pažnje i nudi polivalentnu informaciju, ali ne garantuje pouzdanost." (Gordić-Petković 176) Zato je u pravu Goran Milenković kada ukazuje na "poseban položaj modernog čitaoca virtuelnih prostora" uz objašnjenje da "Linearnost, logika i redosled nestaju u bezdanu Mreže (Interneta)", ali ne i kada zaključuje da "Knjiga nestaje, biblioteke nestaju." (Milenković), barem ne na našim prostorima, gde se - kao što to pokazuju rezultati ovde prikazanog istraživanja - još uvek cene prave vrednosti i tradicionalna knjiga i dalje zauzima mesto koje joj s pravom pripada. Stoga u nešto širim razmerama možemo zaključiti da "Strah da potiskivanje knjige znači apokalipsu kulture" (Gordić-Petković 179) prema rezultatima ovde sprovedene ankete nikako nije opravdan.

\section{Literatura}

Coover, Robert. The end of book. The New York Times, 21 June 1992. Dostupno na: http:// www.nytimes.com/books/98/09/27/specials/coover-end.htm.

Gordić-Petković, Vladislava. Novi mediji i pismenost - poetika ekrana i nove forme čitanja. Kultura, 2011, br. 133, str. 176-183.

Kovačević, Nebojša. O mogućnosti i stvarnosti - jedno (ne)aristotelovsko čitanje e-knjiga. Kultura, 2010, br. 129, str. 20-33.

Milenković, Goran. Fenomen čitanja u svetlu promene nosilaca informacija, 4. maja 2009. Dostupno na: http://biblioteka-bor.org.rs/2009/05/fenomen-citanja.

Trifunović, Bogdan. Elektronske knjige. Glas biblioteke, 2005, br. 12, str. 5-19. 


\author{
Boško Francuski \\ Faculty of Political Science, University of Belgrade \\ Biljana Đorić Francuski \\ Faculty of Philology, University of Belgrade
}

\title{
BOOK BEYOND THE BOOK
}

\section{Summary}

Although the electronic book is the invention of the twentieth century, the traditional - that is to say, printed book has surprisingly managed to survive as a form of traditional culture, all the way until the mid-second decade of the twenty-first century. The popularity of the former, also called e-book, on-line book, e-edition or digital book, has however undeniably been on the rise, and thus the electronic book has been the topic of numerous scientific studies worldwide, related to its various aspects. Unfortunately, the comparison between these two types of book publication has not gained much interest in Serbian academic circles, in spite of the significance of the phenomenon already recognised abroad. Therefore, this paper aims to analyse the role of the book form in the habits and learning environment of Serbian students. The material for this case study has been collected by using a questionnaire filled in by students from different faculties of the University of Belgrade, of various age, that is, at several years of studies. The survey contained not only closed questions, which supplied quantifiable data for the research, but also allowed the respondents to answer in an open-ended manner, which provided qualitative data and helped complete the picture of overall results. The answers have been analysed and by method of deductive reasoning the received data sorted and interpreted with the purpose of defining the attitude of our students regarding the differences between the e-book and the printed book, with a view to gaining an insight into the future of the latter.

Key words: traditional book, e-book, questionnaire, students, University of Belgrade 